GEOGRAFICKÝ ČASOPIS / GEOGRAPHICAL JOURNAL 73 (2021) 3, 219-237

DOI: https://doi.org/10.31577/geogrcas.2021.73.3.12

\title{
THE WORLD JUNIOR SHORT TRACK SPEED SKATING CHAMPIONSHIPS 2018 IN TOMASZÓW MAZOWIECKI: A SPORTS GEOGRAPHY PERSPECTIVE
}

\author{
Waldemar Cudny*, Richard Keith Wright**, Irena Dybska-Jakóbkiewicz***, \\ Blanka Gosik**** \\ * University of Lodz, Faculty of Geographical Sciences, Institute of Urban Geography, Tourism Studies \\ and Geoinformation, Kopcińskiego 31 str, 90-142 Łódź, Poland, waldemar.cudny@geo.uni.lodz.pl \\ ** Auckland University of Technology, School of Sport \& Recreation, Department of Sport Leadership \\ \& Management, Nord Campus 90, Akoranga Drive, Northcote, Auckland, 0627 New Zealand, \\ richard.wright@aut.ac.nz \\ *** Jan Kochanowski University of Kielce, Faculty of Natural Sciences, Institute of Geography \\ and Environmental Sciences, Uniwersytecka 7, 25-406 Kielce, Poland, irena.dybska@ujk.edu.pl \\ **** University of Lodz, Branch, ul. Konstytucji 3 Maja nr 65/67, 97-200 Tomaszów Mazowiecki, Poland, \\ blanka.gosik@wp.p
}

\begin{abstract}
The World Junior Short Track Speed Skating Championships 2018 in Tomaszów Mazowiecki: A sports geography perspective

The sports event sector has increased over the past decades, becoming a profitable part of the leisure and tourism industry. While there is no shortage of knowledge surrounding the legacies of large-scale sports events, little is known about the smaller competitions. The authors seek to fill this gap by establishing a profile of the spectators attending the 2018 World Junior Short Track Speed Skating Championships, hosted in Tomaszów Mazowiecki (Poland). The results were gathered from 349 intercept survey questionnaires. Over half of the respondents were from the host city or the region. The majority were women. The event attractiveness, uniqueness and novelty, including the venue were the main reasons for attendance. The respondents' willingness to attend a similar event in the future was another key finding. The conclusion and recommendations focus on the need for further research into the motives of those attending small-scale indoor, international age-group winter sports events.
\end{abstract}

Key words: Sporting events, sports geography, visitor profile, visitors' motivations, Tomaszów Mazowiecki, Poland

\section{INTRODUCTION}

The size and scale of the international sports event management sector has increased significantly over the past two decades, becoming a very profitable part of the leisure and tourism industry (Shipway and Kirkup 2011, McGillivray et al. 2015, Getz and Page 2016, Frawley 2017 and Wright 2019). Sporting events not only generate tourism activity (Getz 2008) but also have a significant impact on the leisure habits and hobbies of those living within host cities (Dionigi 2001, Cudny 2016 and Wright 2019).

Multifaceted events impacts encompass economic (Dwyer et al. 2006) and socio-cultural development (Schlenker et al. 2005) image-related legacies (Preuss and Alfs 2011), increasing physical activity, health, sports participation and community regeneration (Rogerson 2016 and Grix 2018). Moreover, impacts on urban space and landscape should be included as events legacies (Brown et al. 2015).

Thanks to their positive impacts events create unique development opportunities for places, regions and countries. Events draw from regional attractions, built upon local heritage and culture and create development opportunities for host regions and places. These opportunities include societal and economic development and 
many non-tangible impacts like the aforementioned creation of a positive place or region brand (Wise and Harris 2019). The influence of events on spaces and places is often described as festivalisation or eventification and include multidimensional impacts on a different geographical scale (Cudny 2016).

The multifaceted impacts that sport-related activities (e.g. sporting events) have on host places and regions are also extremely important (Bale 2002). The relationship between sport and geography resulted in the creation of a separate research direction combining the aforementioned elements known as sports geography (Wise and Kohe 2020). Some important research issues in sports geography include among others socio-economic impacts of events on host places and regions (see: Smith 2012, Richards et al. 2013, Wise and Harris 2017 and Aquilino et al. 2020) and image related results of sports activities including place narratives and regional brand creation (see Wise and Harris 2010 and 2017).

According to Li and Petrick (2005), the most important event related research issues include event impacts, event attendees profiling, spectator pre-event expectations (perceptions) and on-site experiences (satisfaction). Moreover, there is also a plethora of studies that explore the spectators' willingness to attend the same or a similar event in the future (McDonald et al. 2002, Saayman and Uys 2003, Lee et al. 2007 and 2008 and Scholtz et al. 2015). What differentiates this case study from the existing body of knowledge is the focus on the movements and motivations of the local residents, the intra-regional attendees/visitors and the inter-regional "domestic" sports event tourists. To date, much of the sports event management literature has looked at larger major/mega-events hosted in large urban centres and/ or the motivations of the international sports events tourist (Wright 2019).

Undertaking event-focused market segmentation and sports event spectator profiling is very important from both a theoretical and practical point of view (Ritchie et al. 2002 and Kruger and Saayman 2016). In sum, having a clear picture of your target audience makes it possible to plan events more efficiently, satisfy the viewers' needs better and run more effective marketing campaigns (Saayman and Uys 2003 and Scholtz et al. 2015). It also helps to estimate the impacts of event tourism and the geographical range of an event. Moreover, knowing the wants and needs of the market also provides the local authorities with crucial information regarding the quality of the events within their portfolio and the development of future event tourism opportunities (Li and Petrick 2005 and Shipway and Kirkup 2011). The article main aim is to present a detailed profile of the spectators attending the 2018 World Junior Short Track Speed Skating Championships in Tomaszow Mazowiecki (Fig. 1), to analyse their main motivations for event attendance and assess the event impacts on the host city.

The aim of the article also encompassed the assessment of the event impact on the tourist traffic and the perception of Tomaszów Mazowiecki in the eyes of event participants. The problem of the impact of events on space in its socio-economic dimension (including the generation of tourist traffic) and the image of a host destination is a geographical issue as it concerns an analysis of various aspects of the geographical space distinguished by Thrift (2003). These impacts include among others the influence of events on Thrift's (2003) space of social and economic connections (i.e. unblocking space), image space and place space (Cudny 2014).

Moreover, the analysis reveals spectators pre-event motivations and post-event satisfaction levels, including the likelihood of return visitation to the event and host 
region. In addition, the paper also reveals local attendee perceptions around the sports event tourism generated within the host city.

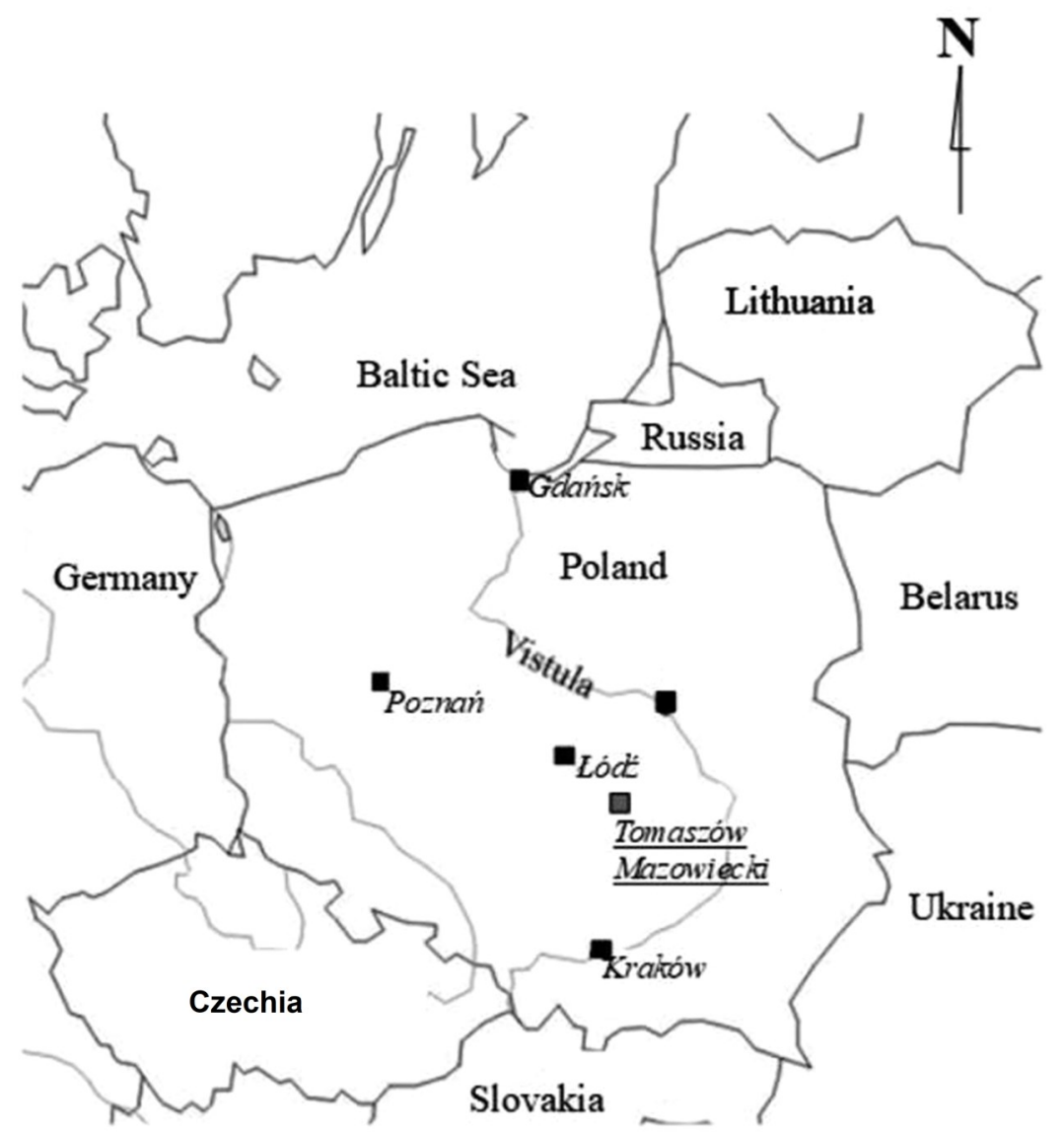

Fig. 1. Tomaszów Mazowiecki: spatial context

The paper is divided into six parts. Following the introduction, the authors present the theoretical framework, a review of the relevant academic literature and an overview of the case study. The final sections present the research results of the data collection and analysis process, a discussion that links these results back to the literature and a conclusion that offers a series of recommendations for future research and for practitioners situated within the event industry.

\section{THEORETICAL FRAMEWORK}

According to Preuss (2007), sports events generate a number of planned and unplanned, negative and positive, tangible and intangible legacies for the host community. These legacies can take a number of different forms and arise are various different times during the event planning and production process. The most common examples located within an ever-expanding library of sports event management literature focus upon urban development and regeneration (Varrel and Kenne- 
dy 2011), infrastructural development (Baade and Matheson 2011), destination image (Chalip and Costa 2005 and Taks et al. 2015), city marketing and brand (Pike 2005 and Smith 2012), tourism (Deery et al. 2004, Hudson 2012 and Getz and Page 2016), employment and business opportunities (Preuss 2007 and Frawley 2017), social cooperation (Wright 2019), and creation of values and community spirit (O'Brien and Chalip 2007).

All events are spatiotemporal phenomena that can be divided up into those that are unplanned (occasional, incidental gatherings of people) and those that are planned (Getz 2008 and Getz and Page 2016). Getz (2008, p. 407) divided planned events into occasional mega-events (high tourist demand and value), periodic hallmark events (high tourist demand and value), regional events (medium tourist demand), and local events (low demand and value). Getz (2008) also distinguished recreational events (with sports activities or games for fun) and sports competitions, including amateur/professional and spectator/participant events. Large scale events are more likely to attract attendees from outside the host region (Solberg and Preuss 2007, Smith 2012). Those who travel to actively participate/compete in sporting events are typically classified as being "active sports tourism" (Gibson 1998, Gibson et al. 2003 and Wright 2019).

Sports tourism has been conceptualised and (re)defined on many occasions (Wright 2019). Weed and Bull (2004, p. 37) offer one of the broadest definitions, referring to it as "a social, economic and cultural phenomenon arising from the unique interaction of activity, people and place". According to Ritchie and Adair $(2004$, p. 8) sports tourism incorporates "all forms of active and passive involvement in a sporting activity, participated in casually or in an organised way for noncommercial or business/commercial reasons, that necessitate the travel away from home and work locality". Weed (2008) simplified the existing definitions even further, claiming sports tourism incorporates all forms of active and passive involvement in a sporting activity, participated in casually or in an organised way for noncommercial or business/commercial reasons, that necessitate the travel away from home and work locality.

The next significant issue concerns the sports event spectators' motivations (McDonald et al. 2002, Lee et al. 2004, Funk et al. 2009, Wang et al. 2013 and Scholtz et al. 2015). Based on the publication by Lee et al. (2004), Cudny and Ogórek (2014) distinguished seven groups of visitors' motivations, which are frequently mentioned in event studies publications. They include event novelty and excitement; escape from everyday routine; social motivations (socialisation with other people, family togetherness); cultural exploration; relaxation and leisure; nature appreciation; entertainment. According to Osti et al. (2012) there are three main groups of visitors' motivations distinguished in event studies. The first group includes motivations related to an escape from the tiresome everyday routine (see: Uysal et al. 1993, Scott 1996, Schneider and Backman 1996 and Lee 2000). In the case of sport event tourists, this group of motivations can be included among push factors (Gibson 1998 and Kim and Lee 2002).

The next group of motivations, according to Osti et al. (2012) includes several elements attracting visitors, such as event novelty, curiosity, desire for adventure and excitement (see: Uysal et al. 1993, Backman et al. 1995 and Lee 2000). This group of motivations may be included among pull factors according to Iso-Ahola (1982), i.e. elements which attract tourists to a given destination (see: Uysal and Jurowski 1994). Events are attractions which draw tourists with their otherness, 
interesting program, unusual atmosphere, presence of famous people (e.g. sports celebrities), the possibility of personal participation in the experience offered by the event. Developed societies have mostly satisfied their basic everyday needs and they are looking for experiences that will let them satisfy their growing higher needs (Schulze 2005). The development of this kind of social needs favours the growth of tourism (Stasiak 2019), including event tourism and sports tourism based on events (Cudny 2016).

The third group of motivations mentioned by Osti et al. (2012) refer to socialization and a desire to meet new people (see: Backman et al. 1995, Schneider and Backman 1996, Crompton and McKay 1997 and Lee 2000). Socialization involves spending more time with friends and family, as well as meeting new people. Events are usually places where people of similar interests meet; they are also an opportunity to relax and make new acquaintances (Cudny 2016).

\section{THE HOST CITY, VENUE AND THE EVENT}

Tomaszów Mazowiecki is a post-industrial town of 63,000 inhabitants (in 2019), situated in the lowlands of Łódź Province, located in the middle of Poland. The size and economic status of the city declined during the early 1990s as a direct consequence of the fall of communism (Cudny 2006). Only after Poland had joined the European Union (2004), did a more profound economic restructuring take place. This included the development of new infrastructure, an influx of new investments and an urban transformation that decreased unemployment and improved local living conditions (Cudny 2019a). In terms of sport and recreation opportunities, for locals and visitors, Tomaszów Mazowiecki lies on the Pilica River and is surrounded by forests. Spała, located $11 \mathrm{~km}$ east of the city, is one of the most important Polish sports centres, where athletes prepare for the Olympic Games. In 2014, the local authorities decided to increase the city's investment and involvement in the development of sport, recreation and tourism (Cudny 2019a).

Tomaszów Mazowiecki is also known for its skating traditions. The "Pilica" sports club has a speed skating section that has been functioning since 1967 and, in 1971, the first naturally frozen skating rink was opened. In the following years, there were continuous attempts made to build an artificially frozen skating rink, which was successfully completed in 1984 (https://www.kspilica.pl/historia). After some years, it was suggested that it should be renovated, but finally, a decision was made to build a new Ice Arena. The idea was supported by the city authorities and the Ministry of Sport and Tourism. The undertaking cost 47.5 million PLN (ca. \$ 13 million) and it was financed by the Ministry and from the local funds. The facility was officially open in December 2017 and, at the time of writing, the Ice Arena was the only all-year-round, indoor skating facility in Poland. It takes up about 1.7 hectares and it can accommodate up to 10,000 spectators.

Tomaszów Mazowiecki's Ice Arena is an element of the sports, recreation and, in part, tourist infrastructure, which is very important for the development of the city and the whole region. The Ice Hall is a training facility for the skating section of the local Pilica sports club and the Polish national skating team. Moreover, the Ice Arena offers the possibility of organizing speed skating sports competitions, regardless of the weather. In addition to the $400 \mathrm{~m}$ long skating track and ice rink, Tomaszów Mazowiecki' Ice Arena is also home to volleyball and basketball courts, a tartan running track and a tennis court. It can also be turned into a concert 
or exhibition venue. There are plans to build a hotel with gastronomic, recreational, conference infrastructure and a parking lot nearby.

The Tomaszów Mazowiecki Ice Arena hosted 16 large events within its first 18 months of operation, 13 of which were sporting events, including four international ones (Tab. 1).

Tab. 1. Major mass events at the Ice Arena in Tomaszów Mazowiecki (2017-2019)

\begin{tabular}{|c|c|c|c|}
\hline Event & Date & Range & Type of event \\
\hline $\begin{array}{l}\text { World Junior Short Track Speed Skating } \\
\text { Championships }\end{array}$ & 2-4 March 2018 & International & Sporting event \\
\hline Polish Speed Skating Championships & 16 - 17 December 2017 & National & Sporting event \\
\hline BAJM band 40th Anniversary & 13 April 2018 & National & Concert \\
\hline $\begin{array}{l}\text { BE ACTIVE TOUR } \\
\text { with Ewa Chodakowska }\end{array}$ & 1 July 2018 & National & Sporting event \\
\hline Love Polish Jazz Festival & $21-23$ September 2018 & National & Festival \\
\hline $\begin{array}{l}\text { XXXIII Polish Senior and Neo-Senior Speed } \\
\text { Skating Championships }\end{array}$ & $26-28$ October 2018 & National & Sporting event \\
\hline Junior Speed Skating World Cup & $24-25$ November 2018 & International & Sporting event \\
\hline Senior Speed Skating World Cup & 7 - 9 December 2018 & International & Sporting event \\
\hline $\begin{array}{l}\text { XXXVIII Polish Sprint Speed Skating } \\
\text { Championships }\end{array}$ & $22-23$ December 2018 & National & Sporting event \\
\hline $\begin{array}{l}\text { Polish Junior Speed Skating Champions- } \\
\text { hips }\end{array}$ & $9-10$ February 2019 & National & Sporting event \\
\hline $\begin{array}{l}\text { Polish Skating Cup (Grand Prix) - } \\
\text { Finals }\end{array}$ & 2-3 March 2019 & National & Sporting event \\
\hline $\begin{array}{l}\text { Polish Masters Speed Skating } \\
\text { Championships }\end{array}$ & 16 - 17 March 2019 & National & Sporting event \\
\hline Polish Speed SkatingChampioships & $16-17$ March 2019 & National & Sporting event \\
\hline Polish Short Track Championships & $15-17$ March 2019 & National & Sporting event \\
\hline 1st Wedding Fairs at the Ice Arena & 28 April 2019 & National & Fairs \\
\hline International Open Skating Competition & 18 August 2019 & International & Sporting event \\
\hline
\end{tabular}

Source: Author's elaboration, based on: https://arenalodowa.pl/

The first major sports event was a three-day event held in March 2018. It was the 25th edition of the annual World Junior Short Track Speed Skating Championships (further referred to as the Championships). The Championships were organized under the auspices of the International Skating Union (ISU) and the Polish Speed Skating Association (PSSA). The ISU is one of the world's oldest sports organizations, propagating skating and organizing international events for figure skating, synchronized skating, speed skating, and short track speed skating (https:// www.isu.org/inside-isu). The PSSA is one of the major Polish skating organizations, responsible for gathering competitors, coaches and activists involved in Polish speed skating (https://pzls.pl/). 'Short track' is an Olympic speed ice-skating category that takes place on a short $(111 \mathrm{~m})$, oval rink. There are four competitors who start the race simultaneously and do not have tracks assigned to them (http:// sport.tvp.p1/1304664/short-track-poznaj-dyscypline). Tomaszów Mazowiecki became only the second Polish city to host the Championships, following Warsaw, which hosted the 2001 and 2013 events respectively.

According to Dawid Brilowski (spokeperson of Polish Speed Skating Association) The 2018 Championships were attended by 197 ice skaters from 39 countries. 
Organizing the competition engaged many people, including 50 volunteers. 1627 tickets were sold across the two days of racing, which took place over the first weekend in March (864 tickets on the Saturday and 763 tickets on the Sunday).

\section{METHODS}

The research methods utilised for this study included participant observation and a questionnaire-based survey. Participant observation is when the researcher becomes a participant in the social process or event being studied (Veal 2006, p. 202). The authors' participation in the event allowed them to observe the behaviour of the organizers, volunteers and spectators over the entire duration of the event.

Survey research in social, economic and behavioural sciences encompasses the data collection from human respondents with the use of a standardised questionnaire. The questionnaire is a list of questions printed or distributed in other forms (e.g. online) devoted to a specified research problem which the research seeks to answer (Saris and Gallhofer 2014). According to Veal (2006, p. 100), questionnaire -based surveys are among the most commonly used techniques in leisure and tourism research. The questionnaire-based survey may take two basic formats a face to face or telephone survey where the interviewer reads the questions to the respondent and record answers or respondent - completed format where the respondent reads questions and write answers. A questionnaire-based survey may be used to obtain quantified information about respondents' opinions about behaviour and attitudes towards specified phenomena.

There are different types of questionnaire surveys including the site or user survey involving the distribution of questionnaires among the users of a specified tourism or leisure site. This type of questionnaire-based survey is often referred to as an intercept survey because respondents are intercepted at or near the tourism destination, site or attraction. Survey data analysis and types of research may take several forms including descriptive analysis. This type of analysis involves the presentation of research with the use of frequencies and mean values describing the respondents' answers regarding their opinions and behaviours (Veal 2006).

The collection of data was conducted exclusively at the Arena, across both days of racing, and the survey contained a mix of (open and closed) questions, divided into several sections (Brinkmann 2013 and Anderson 2015). The first allowed the researcher to capture the respondents' demographics (age, gender, education, place of residence and information about their trip - e.g. company, length of stay, etc.). The second section included detailed questions regarding the motivations behind their decisions to attend the event. The third section included questions on the spectators' activity during the Championships, plus an assessment of different elements of the event experience and their willingness to attend similar events at the same venue.

The researchers conducted 370 questionnaires and 349 correctly filled-in forms were chosen for further analysis. The study was carried out by 20 specially trained students of the University of Łódź. The respondents were intercepted randomly and the questioners tried to obtain an answer from every fifth event participant they met. Persons who had already taken part in the study were excluded in order not to duplicate the results (for method see: Veal 2006 and Kruger and Saayman 2016). A simple descriptive analysis process was adopted to ensure the data collected could be widely distributed to the events key stakeholders. The results of the survey are shared within the following section. 


\section{RESULTS}

\section{Spectator Profile}

The observation revealed that the event was professionally prepared and performed. The safety measures were accordingly applied, entrance gates were numerous thus the ticket control went very smooth. A separate zone was established for the players and sports teams. A press centre was also created within the facility. Distinguishing of these spaces increased the safety during the event and helped in its smooth realisation. Moreover, the spectators were provided with catering services inside the sports hall. The placement of additional toilets outside the facility was an important organisational mistake. This was mentioned as an important problem by the respondents participating in the survey conducted during the event.

The questionnaire-based survey included $52.4 \%$ of women and $47.6 \%$ of men. The respondent's level of education varied. The most numerous were people who had completed university (35.0\%) and secondary $(33.8 \%)$ education. They were followed by those with vocational $(15.2 \%)$, secondary postgraduate $(8.3 \%)$, junior secondary $(6 \%)$ and primary $(1.7 \%)$ education. As regards the age structure, the majority of the respondents (59.9\%) were young people, aged 13-35. With regard to individual age groups, the largest one included people aged 25-35 (31.8\%), 36$45(23.8 \%), 18-24(23.2 \%)$ and $46-55(9.5 \%)$. Other age groups did not make up more than $5 \%(13-17-4.9 \% ; 56-64-4.3 \%$; 66 and over $-2.5 \%)$.

Almost one half (48.7\%) of the respondents came from Tomaszów Mazowiecki and $7.4 \%$ from the Tomaszów powiat, directly surrounding the city (local visitors). $20.6 \%$ arrived from the Lódź Province region (the main administrative region of Tomaszów) (regional visitors). 21.5\% came from areas outside Łódź Province (domestic visitors) and $1.8 \%$ were respondents from abroad (foreign visitors). $81.6 \%$ of the visitors from outside the city came to Tomaszów to participate in the event, $18.4 \%$ - for other purposes (e.g. to visit family or friends) and took part in the event "by the way". Referring to the definition of visitors presented by the UNWTO, a person who arrived in Tomaszów Mazowiecki from outside the city can be included in this category as a traveller "taking a trip to the main destination outside his/her usual environment, for less than a year, for any main purpose (business, leisure or other personal purposes) other than to be employed by a resident entity in the country or place visited" (https://www.unwto.org/glossarytourism-terms).

In the next question, the respondents were asked whether they had arrived alone or in someone's company. $35.5 \%$ responded that they had come with the family, $33.8 \%$ - with friends, $21.0 \%$ - alone, $8.2 \%$ with colleagues (e.g. members of the sports teams participating in the competition), and $1.5 \%$ - with friends and family.

Only $14.3 \%$ of the respondents who came for the event stayed in Tomaszów, usually for two $(28.0 \%)$, one $(18.9 \%)$ or three $(16.0 \%)$ nights. Using UNWTO terminology, $14.3 \%$ of the respondents who stayed overnight can be classified as tourists, because they had left their permanent place of residence, arrived in the visited destination to participate in a sporting event and stayed there overnight (see: https://www.unwto.org/glossary-tourism-terms).

Regarding the question about the activity during the visit, $90.5 \%$ of the respondents described themselves as spectators watching the competition, $3.7 \%$ - as members of the team accompanying the competitor, $0.9 \%$ as journalists reporting the 
event for the media, and $4.9 \%$ chose a different answer (e.g. voluntary work, medical service, security guards).

\section{Visitors' motivations}

According to Iso-Ahola (1982, p. 230) "a motive is an internal factor that arouses, directs, and integrates a person's behaviour". The questionnaire used in the study included questions regarding motivations to participate in the event under research. Based on the review of event motivations, presented by Lee et al. (2004), the study encompassed five main groups of motivations, subdivided into smaller types. The main groups of motivations included those related to: a) sport; b) novelty, curiosity and attractiveness of the event (including the desire to gain new experience); c) an escape from the everyday life routine; d) related to the attractiveness of the event; and e) social contacts during the event (Tab. 2). These motivations match those listed by Osti et al. (2012), referring to participation in sporting events:

- event novelty, curiosity, desire for adventure and excitement,

- socialization and desire to meet new people,

- escape from the daily routine.

Each subgroup was evaluated with respect to its significance to the respondents, on a 1-5 scale (1 - insignificant, 2 - fairly insignificant, 3 - quite significant, 4 significant, 5 - very significant). The significance of individual motivations was established based on a mean value calculated from the number of points allocated to individual motivations by the respondents.

The results show that the most important motivations were those related to the distinctiveness and novelty of the event, as well as its attractiveness (in both cases, the mean index value was 3.9) and sport (3.8). The motivations related to socializing (3.7) and an escape from the everyday life routine (3.6) were less important (Tab. 2.).

As for the subgroups of motivations, the spectators were more strongly motivated by the desire to gain new experience (mean index value 4.0), curiosity (4.0), the desire to gain new experience by participating in an international sporting event (4.0) and the desire to learn new, interesting things (4.0). Thus, the highest-rated subgroups of motivations were those which might be related to the attractiveness of the visited place and the event, i.e. those belonging to the group of pull factors, connected first of all with curiosity, novelty and interesting experiences. It is because the Championships in question were the first international sporting event held in Tomaszów Mazowiecki and its region. Moreover, it was only the third event of this type organized in Poland so far.

Some differences in the significance of motivations can be observed when we compare respondents from Tomaszów Mazowiecki to those from outside the city. The motivations related to the attractiveness of the event are slightly more important to the local residents (index 4.0) than the visitors (3.9). It may arise from the fact that the former have smaller access to large sporting events, which had been lacking in the city before. On the other hand, the visitors from outside the city came from large urban centres (Łódź or Warsaw, both of which are inhabited by over 500,000 people), where large sporting events are organized much more often. 
Tab. 2. Motivations to participate in the event

\begin{tabular}{|c|c|c|c|}
\hline Motivations & Mean & $\begin{array}{c}\text { Mean } \\
\text { inhabitants }\end{array}$ & $\begin{array}{c}\text { Mean } \\
\text { visitors }\end{array}$ \\
\hline Related to sport & 3.8 & 3.7 & 3.9 \\
\hline To have contact with the world of sport & 3.8 & 3.8 & 3.9 \\
\hline To increase knowledge of winter sports & 3.7 & 3.7 & 3.7 \\
\hline To experience a new event - an international sporting event & 4.0 & 4.0 & 4.1 \\
\hline Related to novelty, curiosity and attractiveness of the event & 3.9 & 3.9 & 3.9 \\
\hline To gain new experience & 4.0 & 4.1 & 3.9 \\
\hline To have a kind of adventure with sport & 3.9 & 3.8 & 3.9 \\
\hline Out of curiosity & 4.0 & 4.0 & 4.1 \\
\hline Looking for benefits, experiences enriching me & 3.6 & 3.5 & 3.7 \\
\hline Related to escape from everyday life & 3.6 & 3.8 & 3.6 \\
\hline To escape from the tiresome everyday routine (school, family) & 3.6 & 3.7 & 3.5 \\
\hline To unwind & 3.7 & 3.7 & 3.6 \\
\hline To slow down the everyday pace of life & 3.6 & 3.6 & 3.6 \\
\hline Related to the attractiveness of the event & 3.9 & 4.0 & 3.9 \\
\hline To experience the unique atmosphere of a sports competition & 3.8 & 3.9 & 3.8 \\
\hline To see new, interesting things & 4.0 & 4.0 & 3.9 \\
\hline To see the Ice Arena where the Championships take place & 3.9 & 3.9 & 3.9 \\
\hline Related to social contacts & 3.7 & 3.5 & 3.7 \\
\hline To meet new, interesting people & 3.6 & 3.6 & 3.6 \\
\hline To contact people with similar interests to mine & 3.5 & 3.5 & 3.5 \\
\hline To spend time with friends/colleagues & 3.9 & 3.9 & 3.9 \\
\hline
\end{tabular}

Source: Author's elaboration, based on research.

Motivations related to the sport are more important to the visitors (3.9) than to the residents (3.7). It can be assumed that the visitors who put a lot of effort into travelling to another city came due to their interest in skating and a specific sporting event. The residents see this motivation as less important than curiosity, the desire to live an adventure and participate in a new, interesting event (regardless of its theme). An escape from the everyday routine is a more important motivation for the residents (3.8) than for the visitors (3.6). It has been confirmed that Tomaszów inhabitants have smaller access to various attractions, so they treat the event as an opportunity to escape the everyday routine. In turn, social contacts are a more significant motivation for the visitors (3.7) than the host city residents (3.5) - Tab. 2 .

In the next question, the respondents were asked whether visiting the World Junior Short Track Speed Skating Championships was a unique experience for them. $75.4 \%$ gave an affirmative answer, which confirms that it is the attractiveness of the event and the new experience of visiting a large international sports competition that stands behind its appeal. Modern societies are looking for unique experiences which make their lives more attractive. Schultze (2005) described this phenomenon in his work on experience society. The event sector takes advantage of these tendencies to create events providing entertainment and unique experiences. Festivals and sporting events are a magnet attracting the inhabitants of the host cities and tourists just because that they offer an unusual chance for entertainment and relaxation, so different from ordinary life (Richards 2001). 


\section{Sources of knowledge about the event and its assessment}

One of the aims of the questionnaire was also to establish the sources of knowledge about the event. One third (33.3\%) of the respondents indicated social media as the main source (mainly Facebook). A sizeable number (9.6\%) found information about the Championships on the Internet (mostly PSSA and nasztomaszow websites). Only $8.8 \%$ pointed to the radio (mainly local Radio FaMa), and $5.6 \%$ - to press (mainly the local TIT daily paper). However, most respondents $(42.7 \%)$ indicated other sources. They could quote here which source (previously unspecified) provided them with information about the event. The answers varied but mostly pointed to friends, family (word of mouth) and the posters put up around the city.

The next two questions regarded the event evaluation. The respondents were to indicate its weaknesses and strengths. First, they were asked to allocate points, on a scale from 1 (the lowest) to 5 (the highest), to elements such as information, organization, and venue. The information provided during the event (e.g. regarding smaller events organized during the competition, transport options, etc.) was rated the lowest - at 3.8 points, on average. The respondents evaluated the host venue (Ice Ring) very high at 4.3 points on average. They emphasized that the venue was new, impressive and they liked it. The organization of the event, including the competition schedule, security, sanitary conveniences and gastronomy, were also rated high $(4.1 \mathrm{pt})$.

In the next question, the respondents were asked to briefly assess the event in short words. Up to $92.0 \%$ of the comments were positive, mostly stating that the Championships were a good or very good and successful event, an interesting, new experience, a nice performance, a superb, pleasant, great event, good promotion of the city, etc. Only $8.0 \%$ of the respondents expressed a negative opinion, mostly complaining about the poor organization, insufficient information, and the poor or average quality of the event. The next question regarded potential changes to be introduced in the event. Only 176 answers were collected, the remaining respondents had no opinion. It was usually indicated that the information provided during the event should be improved (24.4\%), similar to the availability and standard of toilets $(11.9 \%)$. Other frequently mentioned drawbacks included music and poor quality sound system $(6.3 \%)$, as well as the scarcity of parking places $(5.7 \%)$.

In the last question, the respondents were asked whether they would be willing to participate in a similar sporting event in Tomaszów Mazowiecki in the future. It was a testing question to check if the event was perceived in a positive way and worth repeating as an experience. Most answers indicate the respondents' willingness to visit a similar event again. Only 46.1\% (61.1\% of Tomaszów residents and $41.2 \%$ of non-residents visitors) said they would come for the next event and $39.5 \%(38.9 \%$ of the city residents and $49.3 \%$ of the non-residents visitors) - that they would probably come. Considerably fewer answers indicated that the respondents would probably not come $(6.3 \%)$ or would definitely not come $(1.4 \%)$. About $6.7 \%$ chose the "I don't know" option.

\section{DISCUSSION AND COLCLUSIONS}

The descriptive analysis presented in this article provides an accurate profile of the spectators who purchased tickets to attend the 2018 World Junior Short Track Speed Skating Championships, held in Tomaszów Mazowiecki (Poland), on 2-4th 
March 2018. The questionnaire-based intercept survey included 349 respondents. The majority of them were women $(52.4 \%)$ and young people aged $13-35(59.9 \%)$. Most respondents were people with the university $(35.0 \%)$ and secondary $(33.8 \%)$ education. A significant factor was the respondents' place of residence because it was the basis for classifying them as visitors and tourists. Due to the clear dominance of local and regional visitors, according to Getz's (2008) division of events, the Championships can be defined as a regional event with medium tourist demand. The next element that was analysed was the motivations of the spectators included in the study. Following the concept developed by Lee et al. (2004), the study was based on groups of motivations related to the sport as well as novelty, curiosity and event attractiveness (the desire for new experiences), social contacts during the event, as well as an escape from the everyday routine. They corresponded to the groups of motivations listed by Osti et al. (2012), referring to participation in sports competitions.

The results show that the most important motivations were those related to the distinctiveness and novelty of the event (curiosity, new experiences), as well as its attractiveness and sport (experience of a new international sporting event, to have contact with sport). In the case of visitors attending the event, these motivations are part of the group of pull factors attracting tourists to a destination distinguished by Iso-Ahola (1982).

The motivations related to socializing and an escape from the everyday life routine were less important. Similar results were obtained by Funk et al. (2009) who highlighted the role of excitement, enjoyment of live performances in sports event attendance motivations together with lower importance of socializing motives. Sholtz et al. (2015) emphasized the role of event novelty and memorable event experience as important motives for participation in sports events. Moreover, the role of novelty and extraordinary experiences as an important motive for event and festival attendance was also pointed out in other scientific publications regarding tourism, event studies (see: Backman et al. 1995, Li and Petrick 2005, Kim 2010, Geus et al. 2016, Mitas and Bastiaansen 2018 and Skavronskaya et al. 2020) and sports events attendance motivations (see: Getz and Andersson 2020 and Jeong et al. 2020).

The event provided new, interesting experiences to the respondents. This was confirmed as important visitors' motivation (see Tab. 2). Moreover, the important role of experiences was presented in the answers to the question of whether the event was a unique experience for the spectators. The core role of extraordinary experiences for event creation, promotion, and event-goers satisfaction was confirmed in the literature (Richards 2001 and Cudny 2016). This is in line with the growing role of interesting unique experiences in contemporary societies (Schulze 2005) and with the important role of experiences creation in the current economy (Pine and Gilmore 2011).

Respondents mostly learned about the event (venue, program, etc.) from social media, websites and radio, as well as family and friends (by word of mouth). These results find confirmation in the literature. Social media are essential communication platforms and marketing tools for events (Lee et al. 2012), including sports events (Leask et al. 2011 and Abeza et al. 2013). The role of word of mouth communication as an important element of event promotion and marketing was also confirmed in the literature (see: Wang et al. 2013). 
The event was rated very highly, with $92 \%$ of positive comments. The greatest strength was the venue (Ice Arena) and organization of the event, while information about the event was rated lower. The respondents indicated the need to improve the system of information, the standard of toilets, music and sound system, as well as the availability of parking space. Most respondents would attend or would probably attend a similar sporting event organized in Tomaszów Mazowiecki again. The role of a positive evaluation of a host destination (attractions, services) in revisit intention is highlighted in the literature. Visitors with positive experience and evaluation are more likely to visit the site again (Chen and Funk 2010). This is also confirmed in the research related to sports events (Brown et al. 2016) and festivals (Cole and Illum 2006).

The research results show that the World Junior Short Track Speed Skating Championships held in 2018, in Tomaszów Mazowiecki, may be regarded as a success if we consider the evaluation of the event and its tourism-generating effect. The percentage of tourists $(14.3 \%$ - if the people staying in the city overnight are regarded as tourists) is considerable for a niche sporting event and matched the preevent expectations. As indicated in the research literature small scale and regional events attract fever visitors than large scale events. However small events also create important economic outcomes for the host city and require less investment than hallmark or mega-events. Moreover, small events (local end regional scale) generate less problems for host places (fewer traffic congestions, lower criminality rate, waste, pollution etc.) - Daniels and Norman (2003), Agha and Taks (2015) and Kwiatkowski et al. (2018) and thus could be destination's chance for the development of sustainable event tourism (Gibson et al. 2012, Duglio and Beltramo 2017 and Malchrowicz-Mośko and Poczta 2018). An advantage of small and regional sports events is that they more under the control of local and regional authorities and the influence of large scale international organisations is limited. Small events also create destination awareness among visitors and in the media and thus they contribute to destination promotion and brand creation (Giampiccoli et al. 2015 and Cudny 2019b and 2021).

The main motivations mentioned by the residents and visitors alike were related to the attractiveness and novelty of the event. Thus, it was a significant asset attracting spectators. Moreover, in all the groups, positive evaluation of the Championships prevails and is confirmed by the respondents' willingness to attend a similar event in the future.

The results presented in this article have a number of limitations that should be considered when interpreting them. There are a small number of articles devoted to niche indoor winter sporting events such as Junior Short Track Speed Skating Championships. Therefore it is difficult to compare the results presented in the article with other publications on similar-scale events and to draw more general conclusions. Another limitation is the list of motivations considered in this article. In future research additional motives could be considered including being a fan of a specific sport discipline or a specific sports team.

Further comparative research should be undertaken regarding the profile and motivations of spectators of such events. In addition, such research should be international in nature and ought to include sporting events representing different disciplines. In addition, further research should include an analysis of the long-term impacts of small sporting events on host cities and local residents. The analysis of various types of event legacies like economic, social and leisure legacies is very 
important for event organizers, sponsors and authorities of host cities (see Brown et al. 2015, Rogerson 2016 and Grix 2018).

Determination of the impact of events on space (geographical, urban, etc.) in its various dimensions (socio-economic, physical, image) is an issue closely related to geography (Cudny 2014). In particular, it is linked to sports geography (Wise and Kohe 2020). The scientific literature provides examples of geographical studies devoted to the structure and motivation of event-goers (Cudny and Ogórek 2014), events impacts on society (Janiskee 1991 and 1994, Gibson and Davidson 2004, Waitt 2008 and Richards et al. 2013), culture (Aldskogious 1993 and De Bres and Davis 2001), economy (Richards and Wilson 2004, Smith 2012, Lorentzen 2013 and Sundbo 2013), place image (Wise and Harris 2010 and 2017) and on geographical space in its physical dimension (Cudny 2016). Festivals and sporting events create legacies that change different dimensions of geographical space. For example, Cudny (2014), referring to the geographical space division developed by Thrift (2003), noted that events affect various aspects of geographic space including space of empirical constructions, space of social and economic connections (i.e. unblocking space), image space and place space in host areas.

Concluding the study presented in this article can be considered as research connected with sports geography. The World Junior Short Track Speed Skating Championships 2018 influenced different aspects of the host city space. The event was an interesting experience attracting goers due to its distinctiveness, novelty, attractiveness and connection with sport. Therefore the event attracted spectators from the city and the region as well as a significant amount of tourists. Therefore it may be treated as a regional event with medium tourist demand. We may presume that the event impacted the space of economic and social connections (i.e. geographical unblocking space as presented by Thrift 2003). The event was very well assessed by the spectators and thus it must also have a positive impact on the image space of Tomaszów Mazowiecki as the host city and tourist destination.

\section{REFERENCES}

ALDSKOGIUS, H. (1993). Festivals and meets: The place of music in 'Summer Sweden'. Geografiska Annaler. Series B, Human Geography, 75, 55-72.

ABEZA, G., O'REILLY, N., REID, I. (2013). Relationship marketing and social media in sport. International Journal of Sport Communication, 6, 120-142.

AGHA, N., TAKS, M. (2015). A theoretical comparison of the economic impact of large and small events. International Journal of Sport Finance, 10, 199-216.

ANDERSON, J. (2015). Understanding human geography: Places and traces. Abingdon (Routledge).

AQUILINO, L., WISE, N. A., HARRIS, J. (2020). Wackiness and event management: The case of the World Alternative Games. Event Management, 24, 567-577.

BACKMAN, K. F, BACKMAN, S. J, UYSAL, M, SUNSHINE, K. M. (1995). Event tourism: An examination of motivations and activities. Festival Management and Event Tourism, 3, 15-24.

BAADE, R., MATHESON, V. (2011). Financing professional sports facilities. North American Association of Sport Economics Working Papaers, 11(2), 2-33.

BALE, J. (2002). Sports geography. London (Routledge).

BROWN, G., SMITH, A., ASSAKER, G. (2016). Revisiting the host city: An empirical examination of sport involvement, place attachment, event satisfaction and spectator intentions at the London Olympics. Tourism Management, 55, 160-172.

BRINKMANN, S. (2013) Qualitative interviewing. New York (Oxford University Press). 
BROWN, G., LEE, I. S., KING, K., SHIPWAY, R. (2015). Eventscapes and the creation of event legacies. Annals of Leisure Research, 18, 510-527.

CHALIP, L., COSTA, C. (2005). Sport event tourism and the destination brand: Towards a general theory. Sport In Society, 8, 218-237. DOI: 10.1080/17430430500108579.

CHEN, N., FUNK, D. C. (2010). Exploring destination image, experience and revisit intention: A comparison of sport and non-sport tourist perceptions. Journal of Sport \& Tourism, 15, 239-259.

COLE, S. T., ILLUM, S. F. (2006). Examining the mediating role of festival visitors' satisfaction in the relationship between service quality and behavioral intentions. Journal of Vacation Marketing, 12, 160-173.

CROMPTON, J. L., McKAY, S. L (1997). Motives of visitors attending festival events. Annals of Tourism Research, 24, 425-439.

CUDNY, W. (2006). Przemiany przestrzenne i funkcjonalne Tomaszowa Mazowieckiego w okresie transformacji ustrojowej. Łódź (Łódzkie Towarzystwo Naukowe).

CUDNY, W. (2014). Festivals as a subject for geographical research. Geografisk TidsskriftDanish Journal of Geography, 114, 132-142.

CUDNY, W. (2016). Festivalisation of urban spaces: Factors, processes and effects. Cham (Springer).

CUDNY, W. (2019a). City branding and promotion: The strategic approach. London (Routledge).

CUDNY, W., ed. (2019b). Urban events, place branding and promotion: Place event marketing. London (Routledge).

CUDNY, W., ed. (2021). Place event marketing in the Asia Pacific region: Branding and promotion in cities. London (Routledge).

CUDNY, W., OGOREK, P. (2014). Segmentation and motivations of the attendees' of the Mediaschool Festival in Łódź, Poland. Bulletin of Geography. Socio-economic Series, 24, 41-56.

DANIELS, M. J., NORMAN, W. C. (2003). Estimating the economic impacts of seven regular sport tourism events. Journal of Sport Tourism, 8, 214-222.

De BRES, K., DAVIS, J. (2001). Celebrating group and place identity: A case study of a new regional festival. Tourism Geographies, 3, 326-337.

DEERY, M., JAGO, L., FREDLINE, L. (2004). Sport tourism or event tourism: Are they one and the same? Journal of Sport \& Tourism, 9, 235-245.

DIONIGI, R. A. (2001). Participant experiences in a special sporting event: The case of the United Games in Bathurst, Australia. Annals of Leisure Research, 4, 17-37.

DUGLIO, S., BELTRAMO, R. (2017). Estimating the economic impacts of a small-scale sport tourism event: The case of the Italo-Swiss mountain trail CollonTrek. Sustainability, 9, 343, 1-17.

DWYER, L., FORSYTH, P., SPURR, R. (2006). Assessing the economic impacts of events: A computable general equilibrium approach. Journal of Travel Research, 45, 59-66.

FRAWLEY, S. (2017). Managing sport mega-events. New York (Routledge).

FUNK, D. C., FILO, K., BEATON, A. A., PRITCHARD, M. (2009). Measuring the motives of sporting event attendance: Bridging the academic-practitioner divide to understanding behavior. Sport Marketing Quarterly, 18, 126-138.

GETZ, D. (2008). Event tourism: Definition, evolution, and research. Tourism Management, 29, 403-428.

GETZ, D., PAGE, S. J. (2016). Event studies: Theory, research and policy for planned events. London-New York (Routledge).

GETZ, D., ANDERSSON, T. (2020). Testing the event travel career trajectory in multiple participation sports. Journal of Sport \& Tourism, 24, 155-176.

GEUS, S. D., RICHARDS, G., TOEPOEL, V. (2016). Conceptualisation and operationalisation of event and festival experiences: Creation of an event experience scale. Scandinavian Journal of Hospitality and Tourism, 16, 274-296. 
GIAMPICCOLI, A., LEE, S. S., NAURIGHT, J. (2015). Destination South Africa: Comparing global sports mega-events and recurring localised sports events in South Africa for tourism and economic development. Current Issues in Tourism, 18, 229-248.

GIBSON, H. J. (1998). Sport tourism: Acritical analysis of research. Sport Management Review, 1, 45-76. DOI: https://doi.org/10.1016/S1441-3523(98)70099-3.

GIBSON, C., DAVIDSON, D. (2004). Tamworth, Australia's 'country music capital': Place marketing, rurality, and resident reactions. Journal of Rural Studies, 20, 387-404.

GIBSON, H. J., WILLMING, C., HOLDNAK, A. (2003). Small-scale event sport tourism: Fans as tourists. Tourism Management, 24, 181-190.

GIBSON, H. J., KAPLANIDOU, K., KANG, S. J. (2012). Small-scale event sport tourism: A case study in sustainable tourism. Sport Management Review, 15, 160-170.

GRIX, J. (2018). Leveraging mega-event legacies. London (Routledge).

HUDSON, S. (2012). Sport and adventure tourism. London (Routledge).

ISO-AHOLA, S. E. (1982). Toward a social psychological theory of tourism motivation: A rejoinder. Annals of Tourism Research, 12, 256-262.

JANISKEE, R. (1994). Some macroscale growth trends in America's community festival industry. Festival Management and Event Tourism, 2, 10-14.

JEONG, Y., KIM, S. K., YU, J. G. (2020). Sustaining sporting destinations through improving tourists' mental and physical health in the tourism environment: The case of Korea. International Journal of Environmental Research and Public Health, 17, 1-14.

KIM, S. S., LEE, C. K. (2002). Push and pull relationships. Annals of Tourism Research, 29, 257-260.

KIM, J. H. (2010) Development of a Scale to Measure Memorable Tourism Experiences. Doctoral dissertation summary. European Journal of Tourism Research, 3, 123-126.

KRUGER, M., SAAYMAN, M. (2016). Experience-based typology of spectators at an international cricket sixes tournament. South African Journal for Research in Sport, Physical Education and Recreation, 38, 91-112, [Online]. Available: https://www.ajol.info/ index.php/sajrs/article/view/141757 [accessed: 30-5-2021].

KWIATKOWSKI, G., DIEDERING, M., OKLEVIK, O. (2018). Profile, patterns of spending and economic impact of event visitors: Evidence from Warnemünder Woche in Germany. Scandinavian Journal of Hospitality and Tourism, 18, 56-71.

LEASK, A., HASSANIEN, A., ROTHSCHILD, P. C. (2011). Social media use in sports and entertainment venues. International Journal of Event and Festival Management, 2, 139-150.

LEE, C. K. (2000). A comparative study of Caucasian and Asian visitors to a Cultural Expo in an Asian setting. Tourism Management, 21, 169-176.

LEE, C. K., LEE, Y. K., WICKS, B. E. (2004). Segmentation of festival motivation by nationality and satisfaction. Tourism Management, 25, 61-70.

LEE, S. Y., PETRICK, J. F., CROMPTON, J. (2007). The roles of quality and intermediary constructs in determining festival attendees' behavioral intention. Journal of Travel Research, 45, 402-412.

LEE, C., LEE, S., BABIN, B. (2008). Festivalscapes and patrons' emotions, satisfaction, and loyalty. Journal of Business Research, 61, 56-64.

LEE, W., XIONG, L., HU, C. (2012). The effect of Facebook users' arousal and valence on intention to go to the festival: Applying an extension of the technology acceptance model. International Journal of Hospitality Management, 31, 819-827.

LI, X., PETRICK, J. F. (2005). A review of festival and event motivation studies. Event Management, 9, 239-245.

LORENTZEN, A. (2012). Sustaining small cities through leisure, culture and experience economy. In Lorentzen, A., Van Heur, B., eds. Cultural political economy of small cities. Oxon (Routledge), pp. 65-79.

MALCHROWICZ-MOSKO, E., POCZTA, J. (2018). A small-scale event and a big impact - is this relationship possible in the world of sport? The meaning of heritage sporting events for sustainable development of tourism - experiences from Poland. Sustainability, 10, 1-19. 
MITAS, O., BASTIAANSEN, M. (2018). Novelty: A mechanism of tourists' enjoyment. Annals of Tourism Research, 72, 98-108.

McDONALD, M. A., MILNE, R. G., HONG, J. (2002). Motivational factors for evaluating sport spectator and participant markets. Sport Marketing Quarterly, 11, 100-113, [Online]. Available https://www.cabdirect.org/cabdirect/abstract/20033025789 [accessed: 22-1-2021].

McGILLIVRAY, D., MCPHERSON, G., CARNICELLI, S. (2015). Sporting and cultural events: Contested legacies. Annals of Leisure Research, 18, 441-444.

O'BRIEN, D., CHALIP, L. (2007). Executive training exercise in sport event leverage. International Journal of Culture, Tourism and Hospitality Research, 1, 296-304.

OSTI, L., DISEGNA, M., BRIDA, J. G. (2012). Repeat visits and intentions to revisit a sporting event and its nearby destinations. Journal of Vacation Marketing, 18, 31-42.

PIKE, S. (2005). Tourism destination branding complexity. Journal of Product \& Brand Management, 14, 258-259.

PINE, B. J., GILMORE, J. H. (2011). The experience economy. Boston (Harvard Business Press).

PREUSS, H. (2007). The conceptualisation and measurement of mega sport event legacies. Journal of sport \& tourism, 12, 207-228.

PREUSS, H., ALFS, C. (2011). Signaling through the 2008 Beijing Olympics - using mega sporting events to change the perception and image of the host. European Sport Management Quarterly, 11, 55-71.

RICHARDS, G., ed. (2001). Cultural attractions and European tourism. Wallingford (Cabi).

RICHARDS, G., WILSON, J. (2004). The impact of cultural events on city image: Rotterdam, cultural capital of Europe 2001. Urban Research, 41, 1931-1951.

RICHARDS, G., De BRITO, M. P., WILKS, L., eds. (2013). Exploring the social impacts of events. London (Routledge).

RITCHIE, J. R. B. (1984). Assessing the impacts of hallmark events: conceptual and research issues. Journal of Travel Research, 23, 2-11

RITCHIE, B., MOSEDALE, L., KING, J. (2002). Profiling sport tourists: The case of Super 12 Rugby Union in the Australian Capital Territory, Australia, Current Issues in Tourism, 5, 33-44. DOI: https://doi.org/10.1080/13683500208667906.

RITCHIE, B. W., ADAIR, D. (2004). Sport tourism: An introduction and overview. In Ritchie, B. W., Adair, D., eds. Sport Tourism. Clevedon (Channel View Publications), pp. $1-29$.

ROGERSON, R. J. (2016). Re-defining temporal notions of event legacy: Lessons from Glasgow's Commonwealth Games. Annals of Leisure Research, 19, 497-518.

SAAYMAN, M., UYS, C. (2003). Profiling spectators at a One-day International Cricket Match, Journal of Sport Tourism, 8, 293-301. DOI: https://doi.org/10.1080/ 1477508032000161582

SARIS, W. E., GALLHOFER, I. N. (2014). Design, evaluation, and analysis of questionnaires for survey research. New York (Wiley).

SCHLENKER, K., EDWARDS, D. C., SHERIDAN, L. (2005). A flexible framework for evaluating the socio-cultural impacts of a small festival. International Journal of Event Management Research, 1, 66-77.

SCHNEIDER, I. E., BACKMAN, S. J. (1996). Cross-cultural equivalence of festival motivations: A study in Jordan. Festival Management and Event Tourism, 4, 139-144.

SCHOLTZ, M., KRUGER, M., SAAYMAN, M. (2015). A motivation-based typology of five-day international test cricket match spectators, African Journal for Physical, Health Education, Recreation and Dance, 21, 1247-1270, [Online]. Available: http:// hdl.handle.net/10394/20708 [accessed: 22-1-2021].

SCHULZE, G. (2005). The experience society. London (Sage).

SHIPWAY, R., KIRKUP, N. (2011). Understanding sport tourism experiences: Exploring the participant-spectator nexus. In Sharpley, R., Stone, P. R., eds. Tourist experience: Contemporary perspectives. London (Routledge), pp.127-139. 
SCOTT, D. (1996). A comparison of visitors' motivations to attend three urban festivals. Festival Management and Event Tourism, 3, 121-128.

SKAVRONSKAYA, L., MOYLE, B., SCOTT, N., KRALJ, A. (2020). The psychology of novelty in memorable tourism experiences. Current Issues in Tourism, 23, 2683-2698.

SMITH, A. (2012). Events and urban regeneration: The strategic use of events to revitalise cities. London (Routledge).

SOLBERG, H. A., PREUSS, H. (2007). Major sport events and long-term tourism impacts. Journal of Sport Management, 21, 213-234.

STASIAK, A. (2019). Przestrzeń turystyczna jako przestrzeń doświadczeń. Prace i Studia Geograficzne, 64, 61-87.

TAKS, M., CHALIP, L., GREEN, B. (2015). Impacts and strategic outcomes from nonmega sport events for local communities. European Sport Management Quarterly, 15, 1-6. DOI: $10.1080 / 16184742.2014 .995116$.

THRIFT, N. (2003). Space: The fundamental stuff of geography. In Holloway, S. L., Rice, S., Valentine, G., eds. Key concepts in geography. London (Sage), pp. 95-108.

UYSAL, M., GAHAN, L., MARTIN, B. (1993). An examination of event motivations A case study. Festival Management and Event Tourism, 1, 5-10.

UYSAL, M., JUROWSKI, C. (1994). Testing the push and pull factors. Annals of tourism research, 21, 844-846.

VARREL, A., KENNEDY, L. (2011). Mega-events and megaprojects. Policy Brief, 3, 1-4.

VEAL, A. J. (2006). Research methods for leisure and tourism: A practical guide. Harlow (Prentice Hall).

WAITT, G. (2008). Urban festivals: Geographies of hype, helplessness and hope. Geography Compass, 2, 513-537.

WANG, T. R., MIN, S. D., KIM, S. K. (2013). Fulfillment of sport spectator motives: The mediation effect of well-being. Social Behavior and Personality: An international journal, 41, 1421-1433.

WEED, M. (2008). Sport \& tourism: A reader (1st ed.). London (Routledge).

WEED, M., BULL, C. (2004). Sports tourism: Participants, policy and providers. Oxford (Elsevier).

WISE, N., HARRIS, J. (2010). Reading Carlos Tevez: Football, geography, and nontested identities in Manchester. International Journal of Sport Communication, 3, 322-335.

WISE, N., HARRIS, J.(2017). Covering 'Captain America' and (re)imagining the USA during the 2014 FIFA Football World Cup. In White, L., ed. Commercial nationalism in tourism. Bristol (Channel View Publications), pp. 251-263.

WISE, N., HARRIS, J. (2019). Events, places and societies: Introducing cases, perspectives and research directions. In Wise, N., Harris, J., eds. Events, places and societies. London (Routledge), pp. 1-9.

WISE, N., KOHE, G. (2020). Sports geography: New approaches, perspectives and directions. Sport in Society, 23, 1-10.

WRIGHT, R. K. (2019). "All the lonely people": Embracing autoethnographic creative analytical practice at the 2017 World Masters Games. Annals of Leisure Research, 22 342-361.

Internet sources:

https://arenalodowa.pl/

https://www.isu.org/inside-isu

https://www.kspilica.pl/historia

https://pzls.pl/

http://sport.tvp.pl/1304664/short-track-poznaj-dyscypline

http://tomaszowmazowiecki.naszemiasto.pl/artykul/arena-lodowa-w-tomaszowie-maz-juzprawie-gotowa-na,4286474,artgal,t,id,tm.html

https://www.unwto.org/glossary-tourism-terms 
Waldemar Cudny, Richard Ke ith, Irena Dybska-Jakóbkiewicz, Blanka Gos ik

\section{MAJSTROVSTVÁ SVETA JUNIOROV V RÝCHLOKORČULOVANÍ NA KRÁTKEJ DRÁHE 2018, TOMASZÓW MAZOWIECKI: PERSPEKTÍVA GEOGRAFIE ŠPORTU}

Tento článok prezentuje detailný profil divákov, ktorí navštívili Majstrovstvá sveta juniorov v rýchlokorčul'ovaní na krátkej dráhe, ktoré sa konali v pol'skom meste Tomaszów Mazowiecki v roku 2018. Odhal'uje motivácie ich účasti na podujatí a úroveň spokojnosti po jeho návšteve, vrátane pravdepodobnosti ich opätovnej návštevy takéhoto podujatia a hostitel'ského regiónu. Okrem toho príspevok odhal'uje, ako vnímajú návštevníci podujatia pochádzajúci z hostitel'ského mesta vplyv tejto športovej udalosti na tamojší cestovný ruch.

Článok je rozdelený na šest' častí. Po úvode autori predstavujú teoretický rámec, prehl'ad dôležitej odbornej literatúry a charakterizujú prípadovú štúdiu. Následne prezentujú výsledky výskumu vyplývajúce zo získaných údajov a ich analýz, diskusiu, ktorá konfrontuje výsledky s literatúrou, a záver, ktorý ponúka sériu odporúčaní pre d’alší výskum a pre odborníkov podiel'ajúcich sa na organizácii podobných podujatí.

Výsledky výskumu ukazujú, že Majstrovstvá sveta juniorov v rýchlokorčul'ovaní na krátkej dráhe 2018 môžeme považovat' za úspešné z hl'adiska hodnotenia podujatia a jeho vplyvu na rozvoj cestovného ruchu. Výsledky poukazujú na skutočnost', že najdôležitejšie dôvody na návštevu tohto podujatia súviseli s jeho osobitost'ou a novost'ou (zaujímavost'ou a novými zážitkami), ako aj s jeho atraktívnost'ou a športom ako takým (skúsenost' s novou športovou udalost'ou, možnost' byt' v kontakte so športom).

Podujatie poskytlo respondentom nové, zaujímavé skúsenosti, ktoré, ako sa potvrdilo, predstavovali aj dôležitú motiváciu pre návštevníkov. O udalosti (mieste konania, programe, atd’.) sa väčšinou dozvedeli zo sociálnych médií, webových stránok a rádia, ako aj od rodinných príslušníkov a priatel'ov (ústnym podaním). Podujatie bolo vel'mi vysoko hodnotené, ked'že získalo až $92 \%$ pozitívnych komentárov. Pri tomto hodnotení najviac zavážilo miesto podujatia (Ice Arena) a samotná jeho organizácia, zatial' čo informácie o podujatí boli hodnotené horšie. Väčšina respondentov by navštívila alebo by pravdepodobne navštívila podobné športové podujatie organizované v meste Tomaszów Mazowiecki znova. 
